\title{
Exercise is associated with better quality of life in patients on TSH- suppressive therapy with levothyroxine for differentiated thyroid carcinoma
}

\author{
O exercício está associado com melhor qualidade de \\ vida em pacientes em terapia de supressão de TSH com \\ levotiroxina para o carcinoma diferenciado de tireoide
}

Patrícia dos Santos Vigário ${ }^{1,2,3}$, Dhiãnah Santini de Oliveira

Chachamovitz², Patrícia de Fátima dos Santos Teixeira² ${ }^{2}$, Maíra

de La Rocque ${ }^{2}$, Maryna Lobo dos Santos², Mário Vaisman²

' Laboratório de Ergoespirometria e Cineantropometria (LErC), Escola de Educação Física e Desportos, Universidade Federal do Rio de Janeiro (UFRJ), Rio de Janeiro, RJ, Brazil

2Serviço de Endocrinologia, Hospital Universitário Clementino Fraga Filho (HUCFF), UFRJ, Rio de Janeiro, RJ, Brazil

${ }_{3}^{3}$ Programa de Pós-graduação em Ciências da Reabilitação, Centro Universitário Augusto Motta, Rio de Janeiro, RJ, Braz
Correspondence to: Patrícia dos Santos Vigário Av. Rainha Elizabeth, 637, ap. 701 22081-030 - Rio de Janeiro, RJ, Brazil patriciavigario@yahoo.com.b

Received on Sept/2/2013 Accepted on Oct/17/2013

\begin{abstract}
Objective: To evaluate if a supervised exercise training program improves the quality of life (QoL) of differentiated thyroid carcinoma (DTC) patients on TSH-suppressive therapy with levothyroxine $\left(\mathrm{L}_{\mathrm{T}} \mathrm{T}_{4}\right.$. Subjects and methods: Initially, a cross-sectional study was performed to compare the OoL and the health-related quality of life (HROoL) between subclinical hyperthyroidism (SCH) patients ( $\mathrm{n}$ $=33$ ) and euthyroid subjects (EU; $n=49$ ). In the prospective phase of the study, SCH patients were randomized in a non-blinded fashion to either participate (SCH-Tr $=$ trained patients; $n=16$ ) or not $(\mathrm{SCH}-\mathrm{Sed}=$ untrained patients; $\mathrm{n}=17)$ in a supervised exercise training program. The exercise program consisted of 60 minutes of aerobic and stretching exercises, twice a week, during twelve weeks. The QoL was assessed by the application of the WHOOOL-Bref, and the SF-36 was used to assess the HROoL. Results: SCH patients had statistically lower scores than EU on the "physical" domain ofWHOQOL-Bref, besides "physical function", "role-physical", "bodily pain", "general health", "vitality", "role-emotional", and "mental-health" domains of SF-36. After three months, SCH-Tr patients showed improvement in the "physical" and "psychological" domains of WHOOOL-Bref $(p<0.05)$, and in the "physical function", "role-physical", "bodily pain", "vitality" and "mental health" domains of SF-36. Conclusion: Patients on TSH-suppressive therapy with L-T for DTC had impaired QoL and HRQoL compared to EU, but it was improved after 3-months of an exercise training program. Exercise seems to play an important role in the follow-up of DTC patients, since it seems to minimize the adverse effects of the treatment on QoL and HRQoL. Arq Bras Endocrinol Metab. 2014;58(3):274-81
\end{abstract}

\section{Keywords}

Exercise; quality of life; thyroid gland; carcinoma

\section{RESUMO}

Objetivo: Avaliar se um programa de exercícios supervisionado melhora a qualidade de vida (QV) de pacientes com carcinoma diferenciado de tireoide (CDT) em tratamento de supressão deTSH com levotirotoxina (L-T $)$. Sujeitos e métodos: Inicialmente, foi feito um estudo cruzado para se comparar a QV e a qualidade de vida relacionada à saúde (QVRS) em pacientes com hipertireoidismo subclínico (HSC, $n=33$ ) e indivíduos eutiroides ( $E U ; n=49$ ). Na fase prospectiva do estudo, os pacientes com HSC foram randomizados de forma não cega para participar (HSC-Tr $=$ pacientes treinados; $n=16$ ) ou não (HSC-Sed = pacientes não treinados; $n=17$ ) de um programa de exercícios supervisionado. 0 programa de exercícios consistiu de 60 minutos de atividade aeróbica e alongamento, duas vezes por semana, por 12 semanas. A qualidade de vida foi avaliada pelos questionários WHOQOL-Bref, e a QVRS pelo SF-36. Resultados: Os pacientes com HSC apresentaram escores estatisticamente mais baixos do que os EU no domínio "físico" do WHOQOL-Bref, além dos domínios "função física", "papel físico", "dor corporal", "saúde geral", "vitalidade", "papel emocional" e "saúde mental” do SF-36. Após três meses, os pacientes HSC-Tr mostraram melhora nos domínios "físico" e "psicológico" do WHOQOL-Bref $(p<0,05)$ e nos domínios "função física", "papel físico", "dor corporal", "vitalidade" e "saúde mental" do SF-36. Conclusão: Os pacientes em terapia de supressão de TSH com L-T4 para CDT apresentaram QV e QVRS afetados negativamente quando comparados com sujeitos EU, mas essas avaliações melhoraram após três meses de um programa de exercícios. 0 exercício parece ter um papel importante no acompanhamento de pacientes com CDT, já que ele parece minimizar os efeitos do tratamento na QV e QVRS. Arq Bras Endocrinol Metab. 2014;58(3):274-81

\section{Descritores}

Exercício; qualidade de vida; tireoide; carcinoma 


\section{INTRODUCTION}

$\mathrm{D}$ ifferentiated thyroid carcinoma is the most frequent endocrine malignant neoplasia, accounting to more cases of death than all other endocrine neoplasms together (1). The overall mortality, however, is less than $10 \%$, and patients have a very high survival rate due to the biological behavior of most tumors, and to the effectiveness of the treatment (2).

Conventional DTC treatment consists of total or partial thyroidectomy, ablation of thyroid tissue remnant with radioiodine administration, and TSH-suppressive therapy with levothyroxine $\left(\mathrm{L}-\mathrm{T}_{4}\right)$, what causes exogenous subclinical hyperthyroidism ( $\mathrm{SCH}) . \mathrm{SCH}$ is an entity characterized by low or undetectable serum TSH concentrations with normal free T4 (fT4) and free T3 (fT3) serum concentrations (3). These biochemical alterations are associated with increased cardiovascular risk (4), fatigue (5), decreased bone mineral density (6), and lower muscle function of upper limbs (7). Thus, DTC patients may experience some signals and symptoms characteristic of DTC besides others related to $\mathrm{SCH}$, resulting in poor quality of life $(8,9)$.

Several observational and clinical trials have demonstrated that physical activity is associated with health benefits after cancer diagnosis (10-12), and in cancer survivors $(5,13)$. According to the American College of Sports Medicine, physical activity is not only feasible but safe during and after cancer treatment, with induced-improvements in aerobic capacity, muscular strength, fatigue and, consequently, quality of life in some cancer survivors (14). Considering this evidence, the adoption of physical activity program as a non-pharmacological therapy in cancer rehabilitation has been increasing nowadays.

Until this moment, little is known about the relationship between physical activity and DTC. Recently, Kitahara and cols. studied the relationship between obesity and thyroid cancer risk using data from five prospective cohorts $(\mathrm{n}=848,932)$. Over 10.0 years of follow-up, it was evidenced that obesity is an independent risk factor for thyroid cancer, since body mass index was positively correlated with thyroid cancer risk, independent of sex (15). On the other hand, the same authors also found that physical inactivity and history of diabetes mellitus were not associated with the risk of thyroid cancer (16).

Data are still limited concerning the effects of physical activity on health outcomes in thyroid cancer survi- vors. Our group observed that DTC patients on TSHsuppressive therapy with $\mathrm{L}_{-} \mathrm{T}_{4}$ had lesser perception of fatigue, increase in muscle mass and reduction in the variables reflecting whole body fat after twelve weeks of 60-minute aerobic and stretching exercises (5). To our knowledge, this is the first study that evaluated the benefits of physical activity in DTC survivors. Since DTC patients have an excellent survival rate, health improvements induced by physical activity are as important as the perception of better quality of life. Therefore, the aim of the study was to evaluate if a supervised exercise training program improves the quality of life of DTC patients on TSH-suppressive therapy with $\mathrm{L}_{-} \mathrm{T}_{4}$.

\section{SUBJECTS AND METHODS}

\section{Study and sample}

Initially, a cross-sectional study was performed to compare the quality of life (QoL) and the health-related quality of life (HRQoL) between SCH patients ( $\mathrm{n}=$ 33,2 men) and euthyroid subjects $(\mathrm{n}=49,7$ men $)$. In the prospective phase of the study, SCH patients were randomized in a non-blinded fashion to either participate $(\mathrm{SCH}-\mathrm{Tr}=$ trained patients; $\mathrm{n}=16$ ) or not ( $\mathrm{SCH}-\mathrm{Sed}=$ untrained patients; $\mathrm{n}=17$ ) in a supervised exercise training program. After three months of intervention (conventional treatment for DTC and exercise training; $\mathrm{SCH}-\mathrm{Tr}$ ) or observation (conventional treatment for DTC; SCH-Sed), all baseline measurements were repeated.

SCH patients were recruited from the Endocrine Clinic of Clementino Fraga Filho Hospital (Universidade Federal do Rio de Janeiro, Brazil). They were all on TSH-suppressive therapy with $\mathrm{L}_{-} \mathrm{T}_{4}$ for DTC for at least six months prior the beginning of the study. Other inclusion criteria were: serum TSH $<0.4 \mathrm{mU} / \mathrm{L}$, serum fT4 levels between 0.8 and $1.9 \mathrm{ng} / \mathrm{dL}$, and absence of functioning thyroid tissue or metastasis (negative whole body radioiodine scan and undetectable serum thyroglobulin).

The control group that participated in the cross-sectional study was composed of euthyroid subjects (EU) with serum TSH and fT4 levels within the reference range, negative thyroid peroxidase antibody (TPO$\mathrm{Ab})$, and no history of thyroid disease.

SCH patients and EU subjects should be $\geq 18$ yearsold and have sedentary lifestyle for at least six months prior the beginning of the study. The exclusion crite- 
ria for both groups were: current smoking, the use of drugs that could interfere with thyroid status (except for $\mathrm{L}-\mathrm{T}_{4}$ in $\mathrm{SCH}$ patients), and any cardiovascular or chronic disease, even if treated. Subjects with muscle or joint alterations that could limit physical activity practice were also excluded.

The study was approved by the local ethics committee, and all participants gave their written informed consent to participate in the study.

\section{Clinical evaluation and Laboratory assays}

At first, all subjects were submitted to a structured interview carried out by an endocrinologist in order to obtain information about history, clinical signs and symptoms of thyroid disease; the use of medications; health-related habits, such smoking, alcohol consumption and physical activity; coronary risk factors and diagnosis of other diseases.

SCH patient hormone profile was obtained from medical records, and EU subjects had hormone profile done at the Clinical Pathology laboratory of the same hospital.

Serum TSH, fT4, and TPO-Ab levels were measured by immunochemiluminescent procedures (Immulite, Diagnostic Products, Los Angeles, CA). Reference ranges for TSH and $\mathrm{fT}_{4}$ were respectively 0.4-4.0 $\mu \mathrm{IU} / \mathrm{mL}$ and 0.9-1.8 ng/dL. Serum levels of TPO $-\mathrm{Ab}$ $>35 \mathrm{IU} / \mathrm{mL}$ were considered positive. The intra-assay coefficients of variation were $3.8-12.5 \%, 4.4-7.5 \%$ and 4.3-5.6\% for TSH, fT4 and TPO-Ab, respectively, and the inter-assay coefficients of variation were $4.6-12.5 \%$, 4.8-9.0\%, and 7.8-10.5\%.

\section{Overall quality of life - WHOQOL-Bref}

The WHOQOL-Bref - The World Health Organization Quality of Life - was used to assess overall QoL, on its translated and validated Portuguese version (17). This instrument has 26 items that produce scores in four domains related to QoL: physical health, psychological health, social relationships, and environment. Domain scores are structured in a positive direction, i.e., higher scores denote better quality of life, ranging from 4 to 20 .

The WHOQOL-Bref self-assessment was performed during the clinical evaluation, under the supervision of an endocrinologist. The internal consistency of the instrument was considered satisfactory $(\alpha=0.88)$ by the Cronbach Alpha coefficient.

\section{Health-related quality of life - SF-36}

The SF-36 - Medical Outcomes Study 36 Item Short-Form Health Survey - was used to assess HRQoL on its translated and validated Portuguese version (18). This instrument has 36 items that produce scores in eight domains related to HRQoL: physical function, general health, vitality, mental health, social function, role-emotional, role-physical, and bodily pain. Domain scores are also structured in a positive direction, ranging from 0 to 100 .

The SF-36 self-assessment was performed during the clinical evaluation, under the supervision of an endocrinologist. The internal consistency of the instrument was considered satisfactory $(\alpha=0.94)$.

\section{Exercise training program}

SCH patients underwent an exercise training program composed of aerobic and stretching exercises, twice a week, during twelve weeks. Aerobic exercises sessions lasted 60 minutes, divided into three phases: warm-up (approximately 5 minutes), main part (approximately 50 minutes), and cool down (approximately 5 minutes). Exercises were performed on a treadmill. Prescription of aerobic exercise was individual, considering the maximum heart hate on the exercise cardiopulmonary testing, as previously described (19), and the aerobic fitness of each patient. During the main part of the exercise, $\mathrm{SCH}$ patients had to keep heart rate between 65 and $75 \%$ of the maximum heart rate, or under the anaerobic threshold heart rate. Heart rate was recorded all along the exercise session by means of a monitor (Polar, USA), and blood pressure was measured every 10 minutes during the exercise session. $\mathrm{SCH}$ patients were advised to keep hydrated.

All exercise sessions were performed at the Physical Education School of the same university, under supervision of a physical educator. SCH-Tr and SCH-Sed maintained $\mathrm{L}-\mathrm{T}_{4}$ replacement during all the study.

\section{Statistical analysis}

Descriptive analyses were presented as medians, $25^{\text {th }}$ and $75^{\text {th }}$ percentiles (interquartile range), and relative frequency. At baseline, comparisons of continuous variables between $\mathrm{SCH}$ patients and EU subjects were determined by the Mann-Whitney U-Test, whereas comparisons of categorical variables were determined using the Fisher's Exact Test. In the prospective phase of the study, comparisons between SCH-Tr, SCH-Sed 
and EU subjects were determined using the Kruskall-Wallis Test, and the differences were identified using the Mann-Whitney U-Test with Bonferroni correction $(\mathrm{p}<0.016)$.

The impact of exercise training program or observation on QoL and HRQoL was assessed using the Wilcoxon Test with the following comparisons: $\mathrm{SCH}-$ $\mathrm{Tr}_{\text {baseline }}$ vs. SCH-Tr $\mathrm{S}_{3 \text { months }}$ and SCH-Sed baseline $_{\text {v }}$ v. SCH$\mathrm{Sed}_{3 \text { months. }}$ Inter-groups comparisons of the impact of the exercise training program or observation on QoL and HRQoL were determined comparing the variations $(\Delta)$ of each group with the Mann-Whitney U-test $(\Delta=$ QoL and HRQoL scores after three months - QoL and HRQoL scores at study baseline).

Differences were statistically significant at $\mathrm{p}<0.05$, and borderline significance was considered at $0.05 \geq \mathrm{p}$ $<0.07$ (SPSS 13.0 for Windows; Inc., Chicago, IL).

\section{RESULTS}

\section{Cross-sectional study}

Baseline clinical characteristics and thyroid hormone profile of $\mathrm{SCH}$ patients and EU subjects are shown in table 1. Most participants of both groups were female who were not on menopause, with body mass index (BMI) classified as overweight (pre-obese) according to the World Health Organization definition (20). There were no differences between the groups with respect to age, menopause status, BMI and gender (all p-values $<0.05)$. SCH patients presented lower serum TSH $(\mathrm{p}=0.04)$ and higher serum fT4 $(\mathrm{p}=0.04)$ levels than EU subjects.
Concerning QoL, SCH patients had lower median scores on physical and environmental domains of WHOQOL-Bref in relation to the other domains. SCH patients and EU subjects statistically differed only in terms of physical domain, which was better in EU subjects $(\mathrm{p}<0.01)($ Table 2$)$.

In the SF-36 analysis, it was observed that $\mathrm{SCH}$ patients had lower median scores on "role-emotional", "vitality", and "bodily pain" domains in comparison to the other domains. SCH patients had systematically lower scores on all domains compared to EU subjects $(\mathrm{p}<$ $0.05)$, excepting for social domain $(\mathrm{p}=0.45)$ (Table 2$)$.

On both instruments, social domain of $\mathrm{SCH}$ patients was not impaired.

\section{Non-blinded randomized controlled trial}

At baseline, SCH-Tr and SCH-Sed patients were well-matched for demographic data, thyroid hormone profile (Table 1), and WHOQOL-Bref and SF-36 scores (Table 2) (all p-values > 0.05).

All SCH patients that composed the SCH-Tr group completed the exercise training program without developing joint and/or muscular alterations, or any other disease.

After three months of exercise training, $\mathrm{SCH}-\mathrm{Tr}$ patients improved median physical and psychological scores of WHOQOL-Bref, with statistical significance (Table 3$)$. Median variations $(\Delta)$ were positive in the four domains $(\mathrm{p}<0.05$ for physical and psychological $)$, pointing to a beneficial effect of exercise training on QoL. SCH-Sed patients did not show any difference on both median scores and variations of WHOQOL-Bref domains (Table 3).

Table 1. Baseline clinical and hormonal characteristics of SCH patients and EU subjects

\begin{tabular}{|c|c|c|c|c|c|c|}
\hline & SCH $(n=33)$ & SCH-Tr $(n=16)$ & SCH-Sed $(n=17)$ & EU $(n=49)$ & p-value ${ }^{*}$ & p-value* \\
\hline Age (years) & $48.0(41.3-50.8)$ & $48.0(39.8-55.0)$ & $48.0(42.0-50.5)$ & $50.0(40.5-56.0)$ & 0.37 & 0.47 \\
\hline Gender (male; \%) & 6.1 & 6.3 & 5.9 & 14.3 & 0.26 & 0.50 \\
\hline Disease duration (years) & $6.0(4.0-10.5)$ & $9.0(3.8-14.3)$ & $6.5(4.3-12.3)$ & - & - & 0.70 \\
\hline TSH (mU/L) & $0.09(0.02-0.2)$ & $0.1(0.1-0.3)$ & $0.05(0.02-0.2)$ & $2.21^{\dagger}(1.57-2.71)$ & 0.04 & $<0.01$ \\
\hline FT4 (ng/dL) & $1.7(1.5-1.8)$ & $1.6(1.5-1.8)$ & $1.7(1.4-1.8)$ & $1.05^{\dagger}(0.98-1.12)$ & 0.04 & $<0.01$ \\
\hline Menopause (yes; \%) & 42.4 & 56.3 & 29.4 & 46.9 & 0.25 & 0.28 \\
\hline BMI $\left(\mathrm{kg} / \mathrm{m}^{2}\right)$ & $26.6(22.0-31.3)$ & $25.4(22.1-30.1)$ & $27.9(22.3-32.6)$ & $27.0(23.6-30.1)$ & 0.51 & 0.63 \\
\hline
\end{tabular}

SCH-Tr: subclinical hyperthyroidism patients that participated of the exercise training program; SCH-Sed: subclinical hyperthyroidism patients that did not participated of the exercise training program; results are presented as median $\left(25^{\text {th }}\right.$ and $75^{\text {th }}$ percentiles) or relative frequency.

${ }^{*}$ Kruskal-Wallis Test (SCH-Tr vs. SCH-Sed vs. EU); statistical significance for $p<0.05$.

${ }^{\dagger}$ Mann-Whitney U-test with Bonferroni correction; statistical significance for $p<0.016$ (SCH-Tr $\neq$ EU; SCH-Sed $\neq$ EU).

¥ Mann-Whitney U-test (SCH vs. EU); statistical significance for $p<0.05$. 
Table 2. Baseline WHOQOL-Bref and SF-36 scores of patients according to the exercise intervention and in euthyroid subjects

\begin{tabular}{|c|c|c|c|c|c|c|}
\hline & SCH $(n=33)$ & SCH-Tr $(n=16)$ & SCH-Sed $(n=17)$ & EU $(n=49)$ & p-value ${ }^{*}$ & p-value* \\
\hline \multicolumn{7}{|c|}{ WHOQOL-Bref domains } \\
\hline Physical & $12.0(10.9-14.7)$ & $12.3(11.1-14.1)$ & $12.6(10.9-14.6)$ & $15.4^{\dagger}(12.7-17.0)$ & $<0.01$ & 0.01 \\
\hline Psychological & $13.7(11.0-15.7)$ & $13.7(12.0-14.7)$ & $13.3(10.0-15.7)$ & $14.0(12.1-15.3)$ & 0.40 & 0.59 \\
\hline Social & $14.0(12.0-16.0)$ & $14.7(11.0-16.0)$ & $14.7(12.0-16.0)$ & $14.7(12.0-17.0)$ & 0.26 & 0.73 \\
\hline Environmental & $12.0(9.5-12.5)$ & $11.8(9.2-12.5)$ & $12.0(10.8-13.0)$ & $12.5(10.5-14.0)$ & 0.16 & 0.22 \\
\hline \multicolumn{7}{|l|}{ SF-36 domains } \\
\hline Physical function & $55.0(36.3-87.5)$ & $55.0(38.8-87.5)$ & $62.5(41.3-88.8)$ & $85.0^{\dagger}(65.0-95.0)$ & $<0.01$ & $<0.01$ \\
\hline Role-physical & $50.0(25.0-100.0)$ & $50.0(25.0-100.0)$ & $50.0(0 .-87.5)$ & $100.0^{\dagger}(75.0-100.0)$ & $<0.01$ & $<0.01$ \\
\hline Bodily pain & $41.0(22.0-84.0)$ & $46.0(41.0-78.5)$ & $51.0(24.3-74.0)$ & $74.0^{\dagger}(51.0-84.0)$ & 0.03 & 0.01 \\
\hline General health & $59.5(41.3-87.0)$ & $57.0(46.8-85.8)$ & $52.0(38.5-77.0)$ & $77.0^{\dagger}(61.0-87.0)$ & 0.02 & $<0.01$ \\
\hline Vitality & $45.0(25.0-55.0)$ & $45.0(40.0-50.0)$ & $40.0(22.5-77.5)$ & $65.0^{\dagger}(50.0-75.0)$ & $<0.01$ & $<0.01$ \\
\hline Social functioning & $75.0(50.0-100.0)$ & $75.0(40.6-100.0)$ & $50.0(37.5-93.8)$ & $87.5(62.5-100.0)$ & 0.45 & 0.13 \\
\hline Role-emotional & $33.3(0.0-100.0)$ & $33.3(0.0-100.0)$ & $33.3(0.0-100.0)$ & $100.0^{\dagger}(66.7-100.0)$ & $<0.01$ & $<0.01$ \\
\hline Mental health & $56.0(36.0-80.0)$ & $56.0(36.0-72.0)$ & $44.0(34.0-80.0)$ & $70.0^{\dagger}(57.0-87.0)$ & 0.02 & $<0.01$ \\
\hline
\end{tabular}

Results are presented as median $\left(25^{\text {th }}\right.$ and $75^{\text {th }}$ percentiles).

* Kruskal-Wallis Test (SCH-Tr vs. SCH-Sed vs. EU); statistical significance for $p<0.05$.

${ }^{\dagger}$ Mann-Whitney U-test with Bonferroni correction; statistical significance for $p<0.016$ (SCH-Tr $\neq$ EU; SCH-Sed $\neq$ EU).

₹ Mann-Whitney U-test (SCH vs. EU); statistical significance for $p<0.05$.

Table 3. WHOQOL-Bref and SF-36 scores of trained and untrained patients after 3 months of physical activity or observation and their median variation from baseline to 3 months

\begin{tabular}{|c|c|c|c|c|}
\hline & \multicolumn{2}{|c|}{ SCH-Tr $(n=16)$} & \multicolumn{2}{|c|}{ SCH-Sed $(n=17)$} \\
\hline & 3 months & $\Delta$ & 3 months & $\Delta$ \\
\hline \multicolumn{5}{|c|}{ WHOQOL-Bref dimensions } \\
\hline Physical & $15.7(12.7-17.6)^{*}$ & $2.6(0.6-4.3)^{\ddagger}$ & $12.6(11.1-13.7)$ & $0.0(-2.1-0.9)$ \\
\hline Psychological & $14.3(13.5-17.0)^{*}$ & $1.3(0.8-2.7)^{\ddagger}$ & $13.3(10.7-14.7)$ & $0.0(-1.0-1.0)$ \\
\hline Social & $14.7(12.3-17.3)$ & $1.3(0.0-3.7)$ & $14.7(12.0-16.0)$ & $0.0(-1.0-1.3)$ \\
\hline Environmental & $12.3(10.5-14.8)$ & $1.4(0.1-2.9)$ & $12.0(10.5-12.8)$ & $0.0(-1.5-1.3)$ \\
\hline \multicolumn{5}{|l|}{ SF-36 domains } \\
\hline Physical function & $82.5(60.0-90.0)^{*}$ & $10.0(0.0-25.0)^{\ddagger}$ & $60.0(52.5-70.0)$ & $-2.5(18.8-5.0)$ \\
\hline Role-physical & $100.0(25.0-100.0)^{\dagger}$ & $0.0(0.0-43.8)$ & $50.0(25.0-100.0)$ & $0.0(-25.0-25.0)$ \\
\hline Bodily pain & $68.0(43.8-84.0)^{*}$ & $11.0(0.0-22.8)^{7}$ & $51.0(40.5-73.0)$ & $-1.0(10.8-19.0)$ \\
\hline General health & $74.5(48.3-92.0)$ & $5.0(-3.8-14.3)^{7}$ & $52.0(36.0-69.5)$ & $-5.0(-15.0-7.5)$ \\
\hline Vitality & $60.0(51.3-96.9)^{\star}$ & $15.0(10.0-35.0)^{\ddagger}$ & $45.0(30.0-60.0)^{*}$ & $5.0(-20.0-15.0)$ \\
\hline Social functioning & $75.0(53.1-96.9)$ & $0.0(-21.9-34.4)$ & $62.5(50.0-81.3)$ & $0.0(-12.5-18.8)$ \\
\hline Role-emotional & $100.0(0.0-100.0)$ & $0.0(0.0-50.0)$ & $33.3(0.0-66.7)$ & $0.0(-33.3-0.0)$ \\
\hline Mental health & $68.0(60.0-79.0)^{*}$ & $12.0(0.0-32.0)^{*}$ & $52.2(40.0-70.0)^{*}$ & $8.0(-12.0-14.0)$ \\
\hline
\end{tabular}

* Wilcoxon test (3 months vs. baseline); statistical significance $-p<0.05$.

† Wilcoxon test (3 months vs. baseline); borderline statistical significance $-p<0.07$.

${ }^{\ddagger}$ Mann-Whitney test (SCH-Tr vs. SCH-Sed); statistical significance $-p<0.05$.

¥ Mann-Whitney test (SCH-Tr vs. SCH-Sed); borderline statistical significance $-p<0.07$.

Regarding HRQoL, SCH-Tr patients had better median scores on all SF-36 domains than baseline values, with statistical significance for "physical function", "role-physical", "bodily pain", "vitality", and "mental health" domains. Median variations were positive for "physical func- tion" ( $\mathrm{p}<0.05)$, "bodily pain" $(\mathrm{p}<0.07)$, "general health" $(\mathrm{p}<0.07)$, "vitality" $(\mathrm{p}<0.05)$, and "mental health" $(\mathrm{p}<$ 0.07) (Table 3). SCH-Sed patients had statistically higher scores on "vitality" and "mental health" domains than baseline values, although without clinical significance. 
Social domain of WHOQOL-Bref and SF-36 remained the same in both groups.

\section{DISCUSSION}

Differentiated thyroid carcinoma is one of the most curable of all cancers (2) with high long-term survival rates. DTC conventional treatment includes TSH-suppressive therapy with ${\mathrm{L}-\mathrm{T}_{4}}_{4}$ to maintain patients subclinicaly hyperthyroid in order to minimize the risk of disease recurrence. Subclinical hyperthyroidism however, is associated with physical and psychological disabilities that could affect negatively QoL (4-7). Furthermore, for some patients, knowing that they have cancer could potentially lead to poor QoL. Therefore, the relationship between thyroid cancer follow-up and QoL has been explored in the last years in order to provide better supportive care to increase survival rates with good QoL.

In this non-blinded randomized controlled trial, SCH patients on TSH-suppressive therapy with ${\mathrm{L}-\mathrm{T}_{4}}_{4}$ for DTC were initially compared with euthyroid subjects in terms of QoL and HRQoL. The groups differed for most of the aspects of QoL and HRQoL, with worse results for $\mathrm{SCH}$ patients.

Lee and cols. found that 316 Korean disease-free survivors of DTC had poor HRQoL compared with sex and age-matched controls, especially in functional domains. The multiple analyses showed that fatigue, anxiety, and depression were the most important factors related to HRQoL impairment (21). Similarly, Husson and cols. investigated the associations between HRQoL, clinical and socio-demographic characteristics and thyroid cancer symptoms in a sample of 306 longterm thyroid cancer survivors. Patients had impairments on cognitive, physical, emotional, role and social functioning of HRQoL compared with age-and sexmatched cancer free controls. Thyroid cancer symptoms (neuromuscular, concentration, sympathetic and psychological problems) were the major determinants of HRQoL rather than clinical and socio-demographic factors alone (22). A study conducted with urban multi-ethnic Asian individuals also revealed that thyroid cancer survivors had poor HRQoL compared with the overall population (23). The social functioning domain was the only one that was preserved, which was also detected in our study. Corroborating these findings, a study performed with 518 thyroid cancer survivors showed that, although thyroid cancer was associated with physical and psychological problems, reported by $64.5 \%$ of patients, they were well integrated in society, including family and work (24).

The time of disease diagnosis and follow-up seems to play an important role on the relationship between thyroid cancer and HRQoL (25-27). Crevenna and cols. studied 150 consecutive patients with DTC and found that the domains "mental health", "role-emotional", "role-physical", "social functioning", and "vitality" were severely impaired on the subgroup of patients with recent diagnosis (until one year). When the role group was considered (mean period of diagnosis $=5.5 \pm 6.0$ years; range $=0-23.0$ years $) \mathrm{HRQoL}$ was positively correlated with the time since initial diagnosis, except the domains "vitality" and "roleemotional", which remained impaired (25). Hoftijzer and cols. observed that cured DTC patients (median duration of cure $=6.34$ years; range $0.3-41.8$ ) had poor QoL in comparison with controls, but the duration of the cure had an important role in predicting QoL (26). Similar findings were also presented by Pelttari and cols. when patients with cured DTC with mean period of initial treatment of 12.4 years $($ range $=$ 5.0-20.0) reported QoL similar to that of the overall population (27).

In the prospective phase of the present study, $\mathrm{SCH}$ patients were randomized in a non-blinded fashion to either participate (SCH-Tr) or not participate $\left(\mathrm{SCH}^{-}\right.$ Sed) in a supervised exercise training program. After three months, SCH-Tr improved for most of the aspects of QoL and HRQoL.

It is well recognized that physical activity is associated with better physical and psychological health and quality of life among diseased and non-diseased populations $(28,29)$. Reviews about the relationship of physical activity and cancer survivors show that physical activity has benefits in improving risk factors associated with cancer prognosis, and it is generally well tolerated during and after treatment without adverse events (30-32). Recently, a systematic review including 40 randomized controlled trials and controlled clinical trials aimed to evaluate the effectiveness of exercise on HRQoL of adult cancer survivors (breast, colorectal, head and neck, lymphoma, and others). The results suggested that exercise has a positive effect on overall and different domains of HRQoL compared with usual care or other non-exercise intervention (32).

To the authors' knowledge, this is the first study to assess the effect of a supervised exercise training 
program on QoL and HRQoL of DTC survivors. Moreover, two widely instruments were used: the WHOQOL-Bref, which is designated to evaluate overall QoL, including some domains that are not directly influenced by health status; and the SF-36, which is designed to evaluate the extent to which the individual usual or expected QoL aspects are affected by a medical condition or its treatment (18). The results showed that exercise also had a positive effect on QoL and HRQoL of DTC patients, as previously described for patients with other types of cancer (32).

Considering that DTC patients generally have good prognosis and long-time survival rate, all strategies that can contribute to a better quality of life of patients should be considered. In this scenario, exercise seems to be an important and effective intervention and, therefore, patients should be encouraged to have an active life. It is important to reinforce that, although it was observed that QoL and HRQoL of SCH-Tr had improved, scientific and clinical evidences about the effect of exercise on health-related outcomes on DTC survivors are still limited. Further studies are required, especially randomized controlled trials.

In summary, patients on TSH-suppressive therapy with $\mathrm{L}_{-} \mathrm{T}_{4}$ for DTC had impaired QoL and HRQoL compared to euthyroid subjects, but they were improved after 3 months of a supervised exercise training program. Therefore, exercise seems to play an important role in the follow-up of DTC patients, since it seems to minimize the adverse effects of the treatment on QoL and HRQoL.

Acknowledgements: this study was supported by research grants from the National Council of Technological and Scientific Development $(\mathrm{CNPq})$.

Disclosure: no potential conflict of interest relevant to this article was reported.

\section{REFERENCES}

1. Wartofsky L. Increasing world incidence of thyroid cancer: increased detection or higher radiation exposure? Hormones (Athens). 2010;9(2):103-8.

2. Pacini F, Castagna M. New insight in the follow-up strategies of differentiated thyroid cancer. J Endocrinol Invest. 2012;35(6 Suppl):36-9.

3. Donangelo I, Braunstein G. Update on subclinical hyperthyroidism. Am Fam Physician. 2011;83(8):933-8.

4. Collet TH, Gussekloo J, Bauer DC, den Elzen WP, Cappola AR, Balmer $\mathrm{P}$, et al. Thyroid Studies Collaboration. Subclinical hyperthyroidism and the risk of coronary heart disease and mortality. Arch Intern Med. 2012;172(10):799-809.
5. Vigário PS, Chachamovitz DS, Cordeiro MF, Teixeira PF, Castro $\mathrm{CL}$, Oliveira FP, et al. Effects of physical activity on body composition and fatigue perception in patients on thyrotropin-suppressive therapy for differentiated thyroid carcinoma. Thyroid. 2011;21(7):695-700.

6. Nicholls JJ, Brassill MJ, Williams GR, Bassett JH. The skeletal consequences of thyrotoxicosis. J Endocrinol. 2012;213(3):209-21.

7. de Oliveira DSC, Vigário PS, Nogueira MFC, de Castro CL, Vaisman M, dos Santos PF. Quality of life, muscle strength, and fatigue perception in patients on suppressive therapy with levothyroxine for differentiated thyroid carcinoma. Am J Clin Oncol. 2013;36(4):354-61.

8. Biondi B, Cooper D. The clinical significance of subclinical thyroid dysfunction. Endocr Rev. 2008;29:76-131.

9. Singer S, LinckeT, Gamper E, Bhaskaran K, Schreiber S, Hinz A, et al. Quality of life in patients with thyroid cancer compared with the general population. Thyroid. 2012;22(2):117-24.

10. Holmes MD, Chen WY, Feskanich D, Kroenke CH, Colditz GA. Physical activity and survival after breast cancer diagnosis. JAMA. 2005;293(20):2479-86.

11. Meyerhardt JA, Heseltine D, Niedzwiecki D, Hollis D, Saltz LB, Mayer RJ, et al. Impact of physical activity on cancer recurrence and survival in patients with stage III colon cancer: findings from CALGB 89803. J Clin Oncol. 2006;24(22):3535-41.

12. Kenfield SA, Stampfer MJ, Giovannucci E, Chan JM. Physical activity and survival after prostate cancer diagnosis in the health professionals follow-up study. J Clin Oncol. 2011;29(6):726-32.

13. Winters-Stone KM, Dobek J, Nail LM, Bennett JA, Leo MC, Torgrimson-Ojerio B, et al. Impact + resistance training improves bone health and body composition in prematurely menopausal breast cancer survivors: a randomized controlled trial. Osteoporos Int. 2013;24(5):1637-46.

14. Schmitz KH, Courneya KS, Matthews C, Demark-Wahnefried W, Galvão DA, Pinto BM, et al. American College of Sports Medicine roundtable on exercise guidelines for cancer survivors. Med Sci Sports Exerc. 2010;42(7):1409-26.

15. Kitahara CM, Platz EA, Freeman LE, Hsing AW, Linet MS, ParkY, et al. Obesity and thyroid cancer risk among U.S. men and women: a pooled analysis of five prospective studies. Cancer Epidemiol Biomarkers Prev. 2011;20(3):464-72.

16. Kitahara CM, Platz EA, Beane Freeman LE, Black A, Hsing AW, Linet MS, et al. Physical activity, diabetes, and thyroid cancer risk: a pooled analysis of five prospective studies. Cancer Causes Control. 2012;23(3):463-71.

17. Fleck MPA, Louzada S, Xavier M, Chachamovich E, Vieira G, Santos $L$, et al. Application of the Portuguese version of the abbreviated instrument of quality life WHOQOL-bref. Rev Saude Publica. 2000;34:178-83.

18. Ciconelli RM, Ferraz MB, Santos W, Meinão I, Quaresma MR. Brazilian-Portuguese version of the SF-36: a reliable and valid quality of life outcome measure. Rev Bras Reumatol. 1999; 39:143-50.

19. Vigário PS, Chachamovitz DS, Teixeira PF, Santos MA, Oliveira FP, Vaisman M. Impaired functional and hemodynamic response to graded exercise testing and its recovery in patients with subclinical hyperthyroidism. Arq Bras Endocrinol Metab. 2011;55(3):20312.

20. Report of a WHO Consultation. Obesity: preventing and managing the global epidemic. World Health Organ Tech Rep Ser. 2000;894:1-253.

21. Lee J,Yun MJ, Nam KH, Chung WY, Soh EY, Park CS. Quality of life and effectiveness comparisons of thyroxine withdrawal, triiodothyronine withdrawal, and recombinant thyroid-stimulating hormone administration for low-dose radioiodine remnant ablation of differentiated thyroid carcinoma. Thyroid. 2010;20(2):173-9. 
22. Husson O, Haak HR, Buffart LM, Nieuwlaat WA, Oranje WA, Mols $F$, et al. Health-related quality of life and disease specific symptoms in long-term thyroid cancer survivors: a study from the population-based PROFILES registry. Acta Oncol. 2013;52(2):249-58.

23. Tan LG, Nan L, Thumboo J, Sundram F, Tan LK, Health-related quality of life in thyroid cancer survivors. Laryngoscope. 2007;117:507-10.

24. Schultz PN, Stava C, Vassilopoulou-Sellin R. Health profiles and quality of life of 518 survivors of thyroid cancer. Head Neck. 2003;25(5):349-56.

25. Crevenna R, Zettinig G, Keilani M, Posch M, Schmidinger M, Pirich $\mathrm{C}$, et al. Quality of life in patients with non-metastatic differentiated thyroid cancer under thyroxine supplementation therapy. Support Care Cancer. 2003;11:597-603.

26. Hoftijzer HC, Heemstra KA, Corssmit EP, van der Klaauw AA, Romijn JA, Smit JW. Quality of life in cured patients with differentiated thyroid carcinoma. J Clin Endocrinol Metab. 2008;93:200-03.

27. Pelttari $H$, Sintonen $H$, Schalin-Jäntti $C$, Välimäki MJ. Health-related quality of life in long-term follow-up of patients with cured
TNM Stage I or II differentiated thyroid carcinoma. Clin Endocrinol (Oxf). 2009;70:493-97.

28. Myers J. The health benefits and economics of physical activity. Curr Sports Med Rep. 2008;7(6):314-6.

29. Vanhees L, De Sutter J, Gelada SN, Doyle F, Prescott E, Cornelissen $\mathrm{V}$, et al. Importance of characteristics and modalities of physical activity and exercise in defining the benefits to cardiovascular health within the general population: recommendations from the EACPR (Part I). Eur J Prev Cardiol. 2012;19(4):670-86.

30. Speck RM, Courneya KS, Mâsse LC, Duval S, Schmitz KH. An update of controlled physical activity trials in cancer survivors: a systematic review and meta-analysis. J Cancer Surviv. 2010;4(2):87-100.

31. Szymlek-Gay EA, Richards R, Egan R. Physical activity among cancer survivors: a literature review. N Z Med J. 2011;124(1337):77-89.

32. Mishra SI, Scherer RW, Geigle PM, Berlanstein DR, Topaloglu O, Gotay CC, et al. Exercise interventions on health-related quality of life for cancer survivors. Cochrane Database Syst Rev. 2012;15:8:CD007566. 